\title{
Assessing the Impact of Religions and Castes on Population Fertility in an EAG District of India
}

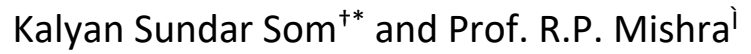

\section{Abstract}

Culture and subculture have given an imprint on social and economic development. Alongside, it has an impact on different aspects of social change and the extent of modernisation in a region. The present study investigates the role of religion and caste in determining the fertility and the causes responsible for religious and caste fertility differential in Sagar district. This district is geographically located in the state of Madhya Pradesh.

To examine the contribution of religion and caste on a change in fertility in temporal scale, both primary and secondary data have been collected and were used for the analysis of the results of this study. The primary data, which was collected through a field survey, were conducted in the study area, and the secondary data were obtained from the Census of India (1981-2011). In order to receive more accurate results, statistical techniques-Multiple Classification Analysis, Logistic Regression Analysis and Decomposition Analysis have been applied. To find out the role of individual socioeconomic characteristics on religious fertility, Multiple classification analysis technique has been used in this study and Logistic regression analysis was applied to probe the likelihood of contraception adoption by the various socioeconomic backgrounds, while, Decomposition analysis has been conducted to probe the religious and caste composition change on temporal scale fertility change.

The findings demonstrate that the Muslim and Scheduled population (Scheduled Castes and Scheduled Tribes) have very high fertility than that of the other segments of society. Moreover, the inclination of fertility transition (from high to low) among other religions (Christians, Sikh and Jain) begins earlier than that of the Hindus, Muslims and Scheduled population. As per the decomposition analysis, the share of Hindu population was more prominent in reducing the fertility which gradually decreased from the decade 1981-91 to 2001-11, while the share of the schedule population and others religions have dramatically decreased during the period. On the other hand, the role of scheduled population and Muslim community has phenomenally increased for changing fertility behaviour. The analysis of the study suggests that education and adequate employment opportunities have reduced the role of religion and caste on fertility in the study area.

Keywords: Religion, Castes, Fertility Behaviour, Parity Progression Ratios, Multiple Classification Analysis, Logistic Regression, and Decomposition Analysis, Madhya Pradesh, India

\footnotetext{
${ }^{\dagger}$ Dr. Harisingh Gour Central University,

${ }^{*}$ Corresponding Author, Email: kalyansundarsom@gmail.com

'Department of General and Applied Geography, Dr. Harisingh Gour Central University

(C) 2019 Som and Mishra. This is an Open Access article distributed under the terms of the Creative Commons Attribution License (http://creativecommons.org/licenses/by/2.0), which permits unrestricted use, distribution, and reproduction in any medium, provided the original work is properly cited.
} 


\section{Introduction}

The fertility of an individual or a population is the outcome of the interplay of the various sociocultural, economic, and demographic indicators. Social status and cultural difference of the people depend on their religion and caste (Som and Mishra, 2017; Patidar,2018; Das and Das, 2018). India has a multi-religious society; however, the two major religious groups (Hindus and Muslims) have long-term concerns for demographers because their share in the society and fertility behaviour continues to remain significant. Studies have however demonstrated that the fertility among the Muslim population has always been higher than that of the Hindus in India (Visaria, 1974; Balasubramanian, 1984; Das\& Pandey, 1985; Sharif, 1999 and Arokiasamy, 2002, Som \& Mishra, 2017). This evidence has been further reinforced by various official sources (Census of India, National Sample Survey Office, National Family Health Survey, District Level Household Survey) indicating that among major religious groups, Muslims have experienced the highest fertility and Sikhs have the lowest in the country (Alagarajan \& Kulkarni 1998; Reddy, 2003). Though some studies find that religion bears no direct impact on fertility, but its impact on fertility bore from different characteristics-use of contraception, and the extent of women's autonomy (Goldscheider \& Uhlenberg, 1969; Day, 1984).

According to the Census of India (2011), the total fertility rate (TFR $\mathrm{Rpr}_{\text {pr }}$ ) of the country was 2.988; it is very high among the Muslim population and stood at 3.562, while among the Hindus it was 2.894 followed by the Sikhs (2.811) and the Buddhists (2.74); and for other religions, it stood at 2.210 (Som\& Mishra, 2017). In the Sagar district, the study area, the TFR $\mathrm{ppr}_{\text {among }}$ Muslims stood at 4.2, which was higher than the
$T_{F R}$ of the Hindus, which stood at 3.74, Jain (2.59)and Christian (2.56) (Census of India, 2011, calculated by the authors). Evidently, castes too play a significant role in controlling fertility behaviour. Officially, in India, caste has been divided into three categories, that is, General Castes, OBC (other backward communities) and SC (Scheduled Castes) \& ST (Scheduled Tribes). ${ }^{1}$ Studies have reported that substantial difference in fertility behaviour has been recorded in the context of increased education (human capital), wealth (economic capital) and higher social status (Bhattacharyya, 2009; 2013; Kulkarni, 2002). However, a village study in the state of Haryana confirmed that fertility was inversely related to caste and socioeconomic status (Arora, 1985). Nonetheless, previous studies have unravelled that the higher fertility is witnessed amongst the Scheduled Castes when compared with the other two (General and OBC) castes (Ramesh, 2007 and Roy et al., 2015). The Scheduled Castes and Scheduled Tribes population have a low level of contraception uses and the lowest level of son preference. It is worth noting here that Hindus' fertility rate is $2.894\left(T_{F R} R_{p r}\right)$ while the fertility rates of Scheduled Castes (3.12) and Tribes (3.48) were recorded as high (Census 2011) in India. A similar scenario has been recorded in the state of Madhya Pradesh and the study area.

This research is an attempt to understand the impact of religious and caste differentials in fertility behaviour in the study area. In doing so, it tries to probe the role of religion and caste on fertility in the present, taking into consideration the historical context in the intersection with other significant variables. In a way, this study tries to address the knowledge gap between fertility and cultural factors (religion and caste)

\footnotetext{
${ }^{1}$ But historically and socially, the caste system is an institution based on jati-varna system. As defined by Risley (1891: p. 875), caste is a "collection of families, bearing, a common name, claiming a common descent from mythical ancestor, human or divine, professing to follow the same hereditary calling and regarded by those who are competent to give an opinion as forming a single homogenous community". Thus, in the caste system, the Brahmins occupy the highest echleon followed by the Kshatriyas (warriors), then the Baishyas (the business class) and the lowest echelon is occupied by the Sudras (one who performs menial tasks) (see, Bhattacharyya, 2009; Bhattacharyya and Singh, 2018 for better understanding of the caste system in India).
} 
in a highly backward district of an $\mathrm{EAG}^{2}$ state (especially the Bundelkhand area).

Sagar district is a part of Bundelkhand which is a backward region of Madhya Pradesh, and this state is one of the EAG states of India (Figure 1). It is interesting to note here that this district has been recorded as one of the very high fertility areas of India. The low sex ratio (893 females per 1000 males) indicates the prevalence of higher gender preference (high preference of male child than a female child). Generally, sex preference increases the fertility rate by achieving the number of gender composition, and the socio-cultural status of the population influences it.

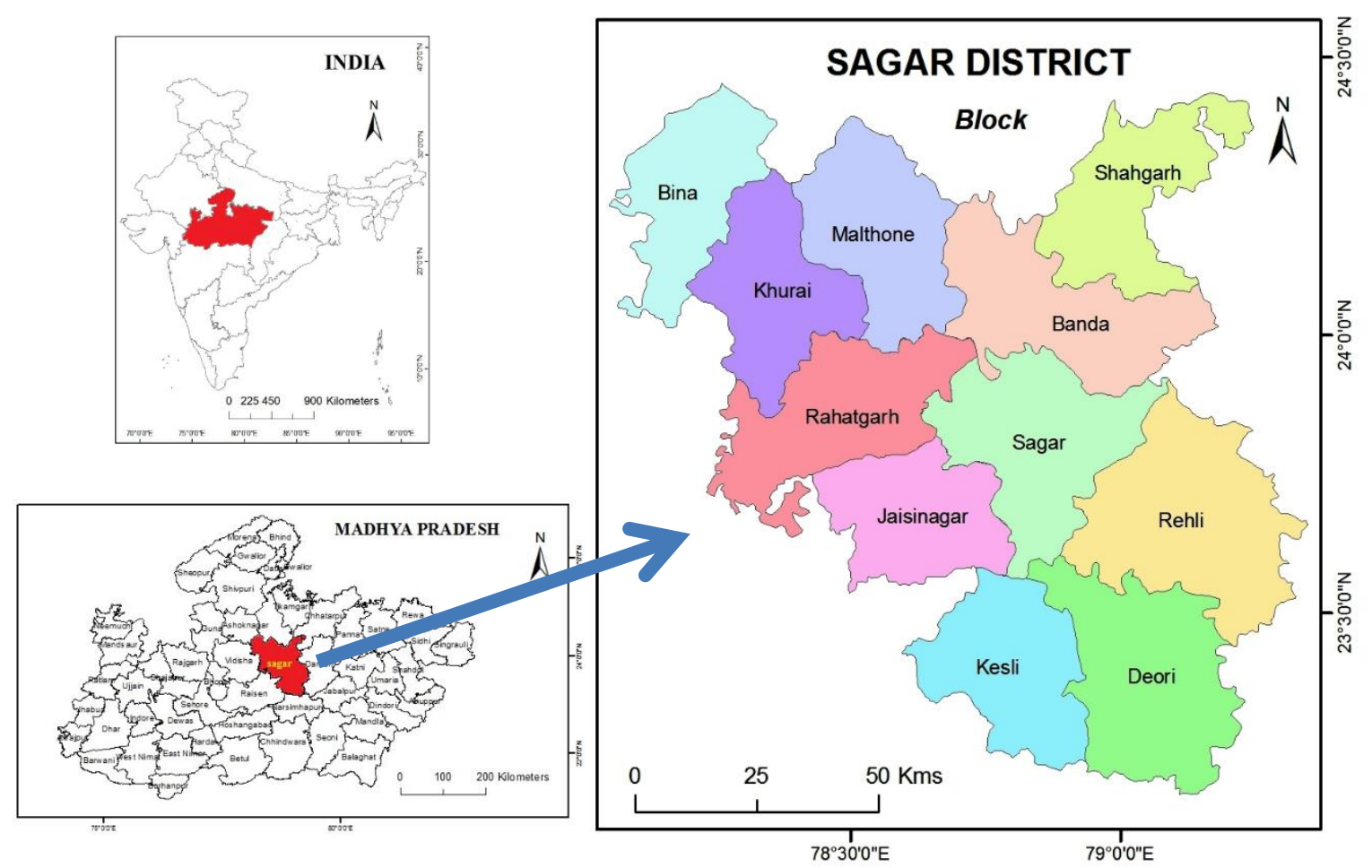

Figure 1: Location Map of the study area (Sagar District)

Source: Survey of India

The religion's faith and traits also influence fertility control measures. Thus, this study aims to find out the complex inter-relationships between religion and caste with that of fertility, fertility preference and contraceptive used. The key objectives and methodological issues are discussed in the following section.

\section{Objectives:}

Previous studies have concluded that religion and castes (Arokiasamy, 2002; Balasubramanian, 1984; Das and Das, 2018; Das \& Pandey,1985; Iyer,2002; Patidar,2018; Ramesh, 2007; Reddy, 2003; Roy et al., 2015; Sharif, 1999; Som and

\footnotetext{
2 EAG states means 'Empowered Action Group of States' which include eight socio-demographic lag behind states (Bihar, Jharkhand, Madhya Pradesh, Chhattisgarh, Uttar
}

Mishra, 2017a; and Visaria,1974) have significant impact on fertility differentials, however, other socio-economic factors are also significant. This study aims to analyse the actual scenario of fertility differentials by religions and castes in the study area, which has received little attention. It also aims to examine the cause which is responsible for religious and caste differentials and their impact on fertility in the study area and aims to know any interaction effect between religion and caste with other relevant socio-economic factors such as place of residence, education level of the respondents, wealth status, and preference for son(s). For this

Pradesh, Uttarakhand, Rajasthan and Odisha) of India (Som and Mishra, 2014) 
primary data have been collected from a field survey using a semi-structured interview schedule from 900 samples of ever-married women $^{3}$ of the reproductive age group (15-49 years). Also, the Census of India fertility (F) Table has been used as a secondary source of data for the analysis using the following steps:

Sampling Techniques: Sagar district has 2.3 million population where 445 thousand women belong to the reproductive age group (Census of India, 2011). To refine the result and cover all the aspects, as stated above, this study has taken 900 samples (of ever-married women) with $99 \%$ confidence level and $4.3 \%$ confidence interval, instead of 95 and 5 per cent. The stratified random sampling techniques were deployed to collect this sample from 11 sample villages of 11 community development blocks, and three wards from three urban centres.

Census Data Tabulation:Here, theCensus data (Table F-2 and F-10) has been used to calculate the parity progression ratio Projected Parity Progression ratio. For this:
- The data from Census Fertility Table, 2011 (F-2) has been used to work out the parity progression ratio (parity by age group of women aged 15-49 or more age group).

- To work out Projected Parity Progression ratio:

○ Fertility Table, 2011 (F-2) has been used to calculate parity by age group of women (aged 15-49 or less).

○ Fertility Table, 2011 (F-10) has been used to calculate the number of children born during the preceding census, classified by mother's age (in five-year groups) and the number of children ever born.

Study Design: Sagar district is mainly dominated by the Hindu population (90.43\%); and others comprise of Muslims (4.35\%), Jain, Christian, Sikh and Buddhist. Here, the Other category is used to include Jain, Christian, Sikh and Buddhist population of the study area.

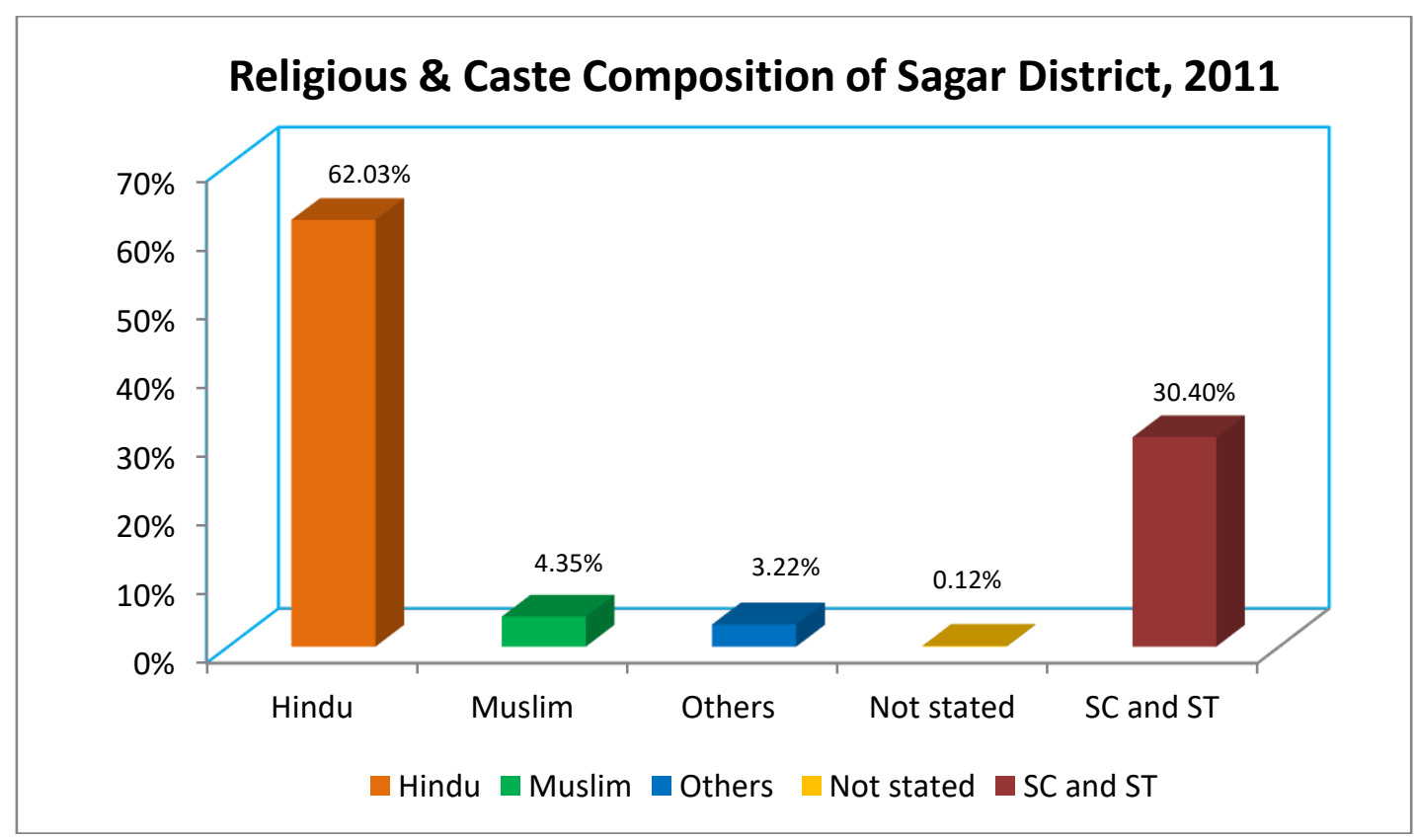

Figure 2: Religious and Caste Composition of Sagar District, 2011

Source: Census of India, 2011

\footnotetext{
${ }^{3}$ Ever married women are those women who have been married at least once in their lives although their current
} 
Among the Hindu population, Scheduled Castes and Tribes have a substantial disparity in a sociocultural context. As mentioned above, this study has considered four religions and caste groups, that is, (i) Hindu excluded Scheduled population (62.03\%), (ii) Muslim population (4.35\%), (iii) Others (3.22 \%), (iv) Scheduled population (30.40 \%) (Figure 2). Here, Scheduled Castes and Scheduled Tribes have been considered as a separate category because officially they are considered as the disadvantaged and marginalised class (Patidar, 2018; Barooah, 2014; see also, Bhattacharyya, 2009; 2013).
Fertility is measured using the samples of currently married women of the reproductive age (15-49 years) and mean children ever born (MCEB). Simple percentage distribution and cross tabulation are also used which is analysed using the Statistical Package for the Social Science (SPSS) software (version 17.0)wherein for the mean children ever born and contraceptive use by religion are taken as the dependent variable and which has crosstabulated using a set of explanatory variables.

To address the objectives mentioned above, this study incorporated the following four methods (Table 1).

\begin{tabular}{|c|c|}
\hline Types of Analysis/Methods & Variables Considered \\
\hline $\begin{array}{l}\text { Family building process: parity } \\
\text { progression ratios }\end{array}$ & $\begin{array}{l}\text { Women who have completed their childbearing age by } \\
\text { attaining } 49 \text { years or by using modern methods of } \\
\text { contraceptives:Tubectomy and Vasectomy. }\end{array}$ \\
\hline $\begin{array}{l}\text { Multiple classification analysis } \\
\text { for the interaction effect }\end{array}$ & $\begin{array}{l}\text { Place of residence, women's educational level, wealth status, } \\
\text { age at marriage, son preference. }\end{array}$ \\
\hline $\begin{array}{l}\text { Logistic regression } \\
\text { (Contraceptive: Users/ } \\
\text { Nonusers) }\end{array}$ & $\begin{array}{l}\text { Residence, women's age, educational level, son preferences, } \\
\text { age at marriage, wealth status and the number of living } \\
\text { children. }\end{array}$ \\
\hline Decomposition analysis & $\begin{array}{l}\text { Mean children ever born, Time series (Decadal Census 1981- } \\
2011 \text { ) }\end{array}$ \\
\hline
\end{tabular}

- Parity progression ratio has been calculated to assess the nature of the family building process for the particular religion and caste category for the period 1981-2011.

- To explore the interaction effect between variables, this study used the analysis of variance (ANOVA) framework by using the sum of squares for the interaction terms. Although there are some limitations up to the level where an interaction effect is significant (or not). Therefore, another method has also been used in this study - to examine the direction and quantum of an interaction effect, and multiple classification analysis has been employed where some new variables are also generated during the analysis of complex relationships between different variables (Table 2).

- To find out the role of religion and caste on the prevalence of contraceptive use; for this, the study has used the binary logistic regression analysis. This analysis employed the dichotomous nature of the dependent variable (adoption of contraceptive). This technique is generally used to examine the influential role of certain variables on the probability of occurrence of an event. A dummy variable constructed here by the combination of contraceptive user and non-user where the user has been assigned the 0 value, and the non-user have been assigned 1 . 
Table 2: Descriptions of Newly Created Explanatory Variables for Multiple Classification Analysis

\begin{tabular}{|c|c|c|c|}
\hline $\begin{array}{l}\text { Religion } x \\
\text { Place of } \\
\text { residence } \\
\text { (grouped; } 4 \times 2 \\
=8 \text { classes) }\end{array}$ & $\begin{array}{l}\text { Religion } \times \text { women } \\
\text { education level (grouped; } 4 \\
\times 5=20 \text { classes) }\end{array}$ & $\begin{array}{l}\text { Religion } x \\
\text { wealth Status } \\
\text { (grouped; } \\
4 \times 5=20 \\
\text { classes) }\end{array}$ & $\begin{array}{l}\text { Religion } \times \text { son preference } \\
\text { (grouped; } 4 \times 2=8 \\
\text { classes) }\end{array}$ \\
\hline \multicolumn{4}{|c|}{$\begin{array}{l}\text { Dependent variable : Mean Children Ever Born (Cumulative } \\
\text { Fertility) }\end{array}$} \\
\hline Hindu - Rural & Hindu - Illiterate & Hindu -Lowest & Hindu -Parity equilibrium \\
\hline Muslim- Rural & Muslim- Illiterate & Muslim- Lowest & Muslim- Parity equilibrium \\
\hline Others - Rural & Others - Illiterate & Others -Lowest & Others - Parity equilibrium \\
\hline $\begin{array}{l}\text { Scheduled - } \\
\text { Rural }\end{array}$ & Scheduled - Illiterate & $\begin{array}{l}\text { Scheduled- } \\
\text { Lowest }\end{array}$ & $\begin{array}{l}\text { Scheduled - Parity } \\
\text { equilibrium }\end{array}$ \\
\hline Hindu - Urban & Hindu - Primary & Hindu -Second & Hindu -Son Preference \\
\hline Muslim- Urban & Muslim- Primary & Muslim- Second & Muslim- Son Preference \\
\hline Others - Urban & Others - Primary & Others -Second & Others - Son Preference \\
\hline \multirow[t]{13}{*}{$\begin{array}{l}\text { Scheduled - } \\
\text { Urban }\end{array}$} & Scheduled - Primary & $\begin{array}{l}\text { Scheduled- } \\
\text { Second }\end{array}$ & $\begin{array}{l}\text { Scheduled - Son } \\
\text { Preference }\end{array}$ \\
\hline & Hindu - Secondary & Hindu -Middle & \\
\hline & Muslim-Secondary & Muslim- Middle & \\
\hline & Others - Secondary & Others -Middle & \\
\hline & Scheduled - Secondary & $\begin{array}{l}\text { Scheduled - } \\
\text { Middle }\end{array}$ & \\
\hline & Hindu -Intermediate & Hindu -Fourth & \\
\hline & Muslim- Intermediate & Muslim- Fourth & \\
\hline & Others - Intermediate & Others -Fourth & \\
\hline & Scheduled - Intermediate & $\begin{array}{l}\text { Scheduled - } \\
\text { Fourth }\end{array}$ & \\
\hline & Hindu - Graduate and Above & Hindu-Highest & \\
\hline & $\begin{array}{l}\text { Muslim- Graduate and } \\
\text { Above }\end{array}$ & Muslim- Highest & \\
\hline & Others - Graduate and Above & Others -Highest & \\
\hline & $\begin{array}{l}\text { Scheduled - Graduate and } \\
\text { Above }\end{array}$ & $\begin{array}{l}\text { Scheduled - } \\
\text { Highest }\end{array}$ & \\
\hline
\end{tabular}


- This study also tries to examine whether there is any change in the contribution of religion and caste composition on fertility decline over the years by decomposition analysis. To fulfil this objective, this study used the methodology adopted by Bhat (2002). Mathematically, the formula of decomposition is expressed as:

$$
\begin{aligned}
& (F b-F a)=\sum_{i=1}^{k} \mathrm{Fb}, \mathrm{i} \times \mathrm{Cb}, \mathrm{i} \\
& -\sum_{i=1}^{k} \mathrm{Fa}, \mathrm{i} \times \mathrm{Ca}, \mathrm{i} \\
& =(\mathrm{Fb}, 1-\mathrm{Fa}, 1) \quad(\mathrm{Cb}, 1+\mathrm{Ca}, 1) / 2+
\end{aligned}
$$

Where, $\mathrm{Fa}, \mathrm{i}=$ The mean children ever born of religion and caste class $\mathbf{i}$ at the time $\mathbf{a}$.

$\mathrm{Fb}, \mathrm{i}=$ The mean children ever born of religion and caste class $\mathbf{i}$ at the time $\mathbf{b}$.

$\mathrm{Ca}, \mathrm{i}=$ Proportion of women of the religion and caste class $i$ at the time a.

$\mathrm{Cb}, \mathrm{i}=$ Proportion change of women of the religion and caste class $\mathbf{i}$ at the time $\mathbf{b}$.

\section{Results and Discussion}

\section{Background Characteristic by the Religious and Caste Groups}

Table 3 shows the percentage distribution of currently married women of reproductive age (15-49 years) and the respondents' background characteristics by religious and caste groups (place of residence, age group, level of education, age at marriage and son preference).

In all religion and caste groups, the proportion of the respondents in the lower age group (15-19 years) varies from $8.00 \%$ (lowest) among the Hindus to $13.60 \%$ (highest) among the Scheduled Castes and Tribes in the study. At the time of the survey, married women respondents in the age group of 15 to 19 years were not found in other religious groups (but those found belonged to the Jain community). The higher percentage of age at marriage is seen in 20 to 34 years age group concerning all the religion and caste groups. Moreover, post-34, the rate of marriage is decreasing. It was not surprising to find that most of the Scheduled population belongs to the lowest two quintiles of wealth status (Barooah, 2014; Patidar, 2018).

On the other hand, in the other religion group (mostly Jains), that is, $91.01 \%$ belongs to higher two quintiles of wealth status. Our research revealed that the wealth status of Hindus population is comparatively fair among five wealth quintile when compared to the Muslim religious group (Table 3 ). The Scheduled population mostly dwells in villages for their livelihood and depends on primary activities such as agriculture. On the other hand, the Jain community is mostly business class, and they live in urban areas for their occupation.

It was saddening to note that the majority of the population (mainly women), that is, 69.87 per cent belonging to Scheduled Castes and Tribes attaining marriage before the legal age (18 years and above for women and 21 years and above for men) are very high while for other religious groups, it is $9.09 \%$. In the case of Hindus, the share of lower age at marriage is higher when compared to their Muslim counterparts. Son preference is lowest amongst the Scheduled community while it is higher in the Muslim and Hindu religious groups.

\section{Religion and Caste: Fertility Differentials}

Table 4 shows the religious and caste wise fertility differentials by various background characteristics. The Muslim population has recorded the least rural-urban fertility differential than the Others. On the other hand, the Hindus excluding the Scheduled Castes and Tribes population, fertility has a clear decreasing trend from uneducated to highly educated while this trend is not evident in other religions and caste communities. Contraceptive users have very low fertility than the non-users in the Muslim community, though the rate of adoption is meagre. 
Wealth prosperity enhances the opportunity of good health and educational facilities bearing low fertility rates. This is true among all the religious and caste communities. However, the relations between wealth category and fertility differentials relation have not been clearly recorded in Muslim and Scheduled communities. Lower age at marriage indicates the higher reproductive span, which also increases the probability of the higher number of children.
High son preference prevails in the study area because the majority of the respondents and their family member perceive that son is more beneficial from the economic point of view as the son will carry, no burden of dowry at the time of marriage. Besides, it is believed that the son would serve as a support mechanism both financially and physically during the old age of the parents.

\begin{tabular}{|c|c|c|c|c|}
\hline \multirow[t]{3}{*}{ Background Characteristics } & \multicolumn{4}{|c|}{ Percentage } \\
\hline & \multicolumn{4}{|c|}{$(N=900)$} \\
\hline & $\begin{array}{l}\text { Hindu exclude } \\
\text { Scheduled }\end{array}$ & Muslim & $\begin{array}{l}\text { Others } \\
\text { religion } \\
\text { group (Jain, } \\
\text { Sikh and } \\
\text { Christian) }\end{array}$ & $\begin{array}{c}\text { Scheduled } \\
\text { Caste and Tribe }\end{array}$ \\
\hline \multicolumn{5}{|c|}{ Place of Residence } \\
\hline Rural & 76.00 & 62.69 & 57.58 & 83.73 \\
\hline Urban & 24.00 & 37.31 & 42.42 & 16.27 \\
\hline \multicolumn{5}{|c|}{ Age Groups } \\
\hline $15-19$ & 8.00 & 10.45 & 0.00 & 13.60 \\
\hline $20-24$ & 23.06 & 11.94 & 12.12 & 21.60 \\
\hline $25-29$ & 23.76 & 22.39 & 45.45 & 16.27 \\
\hline $30-34$ & 18.12 & 13.43 & 24.24 & 17.87 \\
\hline $35-39$ & 15.53 & 14.93 & 18.18 & 10.40 \\
\hline $40-44$ & 5.88 & 22.39 & 0.00 & 11.20 \\
\hline $45-49$ & 5.65 & 4.48 & 0.00 & 9.07 \\
\hline \multicolumn{5}{|c|}{ Education of the Respondents } \\
\hline Illiterate & 29.65 & 41.79 & 0.00 & 50.93 \\
\hline Primary & 31.53 & 23.88 & 3.03 & 35.47 \\
\hline High School & 27.29 & 25.37 & 45.45 & 12.00 \\
\hline Intermediate & 4.00 & 8.96 & 15.15 & 0.80 \\
\hline Graduation and Above & 7.53 & 0.00 & 36.36 & 0.80 \\
\hline \multicolumn{5}{|c|}{ Wealth Status } \\
\hline Lowest & 31.06 & 38.81 & 0.00 & 46.40 \\
\hline Second & 19.29 & 26.87 & 6.06 & 26.13 \\
\hline Middle & 16.24 & 17.91 & 3.03 & 13.60 \\
\hline Fourth & 18.35 & 7.46 & 24.24 & 9.07 \\
\hline Highest & 15.06 & 8.96 & 66.67 & 4.80 \\
\hline \multicolumn{5}{|c|}{ Age at Marriage of the Respondents } \\
\hline Below 18 years & 48.47 & 37.31 & 9.09 & 69.87 \\
\hline 18 years and above & 51.53 & 62.69 & 90.91 & 30.13 \\
\hline \multicolumn{5}{|c|}{ Son Preference of the Couple } \\
\hline Yes & 50.67 & 56.72 & 51.52 & 48.24 \\
\hline No & 49.33 & 43.28 & 48.48 & 51.76 \\
\hline
\end{tabular}

\section{Nature of Family Building Process (Parity Progression Ratio)}

Parity progression ratio (PPRs) is one of the best indicators to examine the family building process and fertility transition (Frejka \& Sardon, 2007 and Holzer-Zelazewska \& Tymicki, 2009).In the present study, PPRs have been computed for those women who have surpassed their childbearing age (49 years) or have adopted a 
permanent method of contraception (Yadava et al., 2009), but this computation has been done separately for four religious-caste groups.

Table 4: Religious and Caste group wise Fertility (MCEB) by Background Characteristics of Sagar District

\begin{tabular}{|c|c|c|c|c|}
\hline & $\begin{array}{l}\text { Hindu } \\
\text { excluding } \\
\text { Schedule } \\
\text { Castes and } \\
\text { Tribes }\end{array}$ & Muslim & $\begin{array}{l}\text { Others } \\
\text { religion } \\
\text { group }\end{array}$ & $\begin{array}{l}\text { Scheduled } \\
\text { Community(Castes } \\
\text { and Tribes) }\end{array}$ \\
\hline \multicolumn{5}{|l|}{ Place of Residence } \\
\hline Rural & 3.25 & 4.07 & 2.21 & 3.89 \\
\hline Urban & 2.71 & 3.76 & 2.07 & 3.23 \\
\hline \multicolumn{5}{|c|}{ The educational level of the respondents } \\
\hline No education & 4.02 & 5.04 & NA & 4.73 \\
\hline Primary standard & 3.27 & 3.81 & 1.00 & 3.03 \\
\hline High school & 2.36 & 2.53 & 2.33 & 2.21 \\
\hline Intermediate & 2.27 & 3.33 & 2.00 & 3.00 \\
\hline Graduation and above & 2.09 & NA & 2.08 & 1.33 \\
\hline \multicolumn{5}{|c|}{ Current use of contraceptive (other than sterilisation) } \\
\hline Not using & 3.31 & 4.22 & 2.33 & 4.11 \\
\hline Using & 2.90 & 2.85 & 2.00 & 4.00 \\
\hline \multicolumn{5}{|c|}{ Wealth status of the family } \\
\hline Poorest & 3.62 & 4.08 & NA & 4.14 \\
\hline Second & 3.41 & 4.33 & 3.00 & 3.92 \\
\hline Middle & 3.32 & 3.75 & 2.00 & 2.96 \\
\hline Fourth & 2.47 & 3.40 & 2.25 & 3.09 \\
\hline Richest & 2.31 & 3.17 & 2.05 & 3.22 \\
\hline \multicolumn{5}{|c|}{ Age at the marriage of respondents } \\
\hline Below 18 years & 3.75 & 4.08 & 2.67 & 3.88 \\
\hline At 18 and above years & 2.52 & 3.88 & 2.10 & 3.56 \\
\hline \multicolumn{5}{|l|}{ Son Preference } \\
\hline Parity equilibrium & 2.45 & 3.36 & 2.06 & 3.24 \\
\hline More Sons & 3.82 & 4.31 & 2.24 & 4.33 \\
\hline
\end{tabular}

Table 5: Parity Progression Ratio by Religious and Caste Group in Sagar District, 2016

\begin{tabular}{|c|c|c|c|c|c|c|c|c|}
\hline \multirow[t]{2}{*}{ Parity } & \multicolumn{2}{|c|}{$\begin{array}{c}\text { Hindus without Scheduled } \\
\text { Castes and Tribes }\end{array}$} & \multicolumn{2}{|c|}{ Muslims } & \multicolumn{2}{|c|}{ Others religious group } & \multicolumn{2}{|c|}{$\begin{array}{c}\text { Scheduled Castes and } \\
\text { Tribes }\end{array}$} \\
\hline & PPRs & CPPR & PPRs & CPPR & PPRs & CPPR & PPRs & CPPR \\
\hline 0 & 0.9572 & & 0.9522 & & 0.9573 & & 0.9514 & \\
\hline 1 & 0.9535 & 0.9572 & 0.9456 & 0.9522 & 0.9287 & 0.9573 & 0.9468 & 0.9514 \\
\hline 2 & 0.8709 & 0.9127 & 0.8994 & 0.9004 & 0.7019 & 0.8890 & 0.9043 & 0.9008 \\
\hline 3 & 0.7535 & 0.8304 & 0.8247 & 0.8505 & 0.4835 & 0.6519 & 0.8520 & 0.8562 \\
\hline 4 & 0.6628 & 0.6562 & 0.7249 & 0.7417 & 0.3777 & 0.3394 & 0.7773 & 0.7705 \\
\hline 5 & 0.6259 & 0.4994 & 0.6767 & 0.5978 & 0.3744 & 0.1826 & 0.7507 & 0.6623 \\
\hline 6 & 0.5952 & 0.4148 & 0.6590 & 0.4905 & 0.3412 & 0.1414 & 0.6528 & 0.5835 \\
\hline 7 & 0.5436 & 0.3725 & 0.5961 & 0.4459 & 0.1941 & 0.1277 & 0.5851 & 0.4901 \\
\hline 8 & 0.3251 & 0.3236 & 0.5031 & 0.3928 & 0.0612 & 0.0662 & 0.5016 & 0.3820 \\
\hline 9 & 0.1806 & 0.1767 & 0.4238 & 0.2999 & 0.0000 & 0.0119 & 0.4318 & 0.2935 \\
\hline 10 & 0.0000 & 0.0587 & 0.3351 & 0.2132 & 0.0000 & 0.0000 & 0.3219 & 0.2166 \\
\hline 11 & 0.0000 & 0.0000 & 0.0000 & 0.1420 & 0.0000 & 0.0000 & 0.0000 & 0.1390 \\
\hline
\end{tabular}


Table 5 demonstrates a detailed trend in PPRs for the first parity (from a woman's birth to her first childbirth), which is very low and have been Compound parity progression ratio is a refinement of PPRs, which has been calculated by the multiplication product of one order parity ratio with next order parity ratio (that is, 0 to 1 order PPRs multiplication with 1 to 2 order PPRs). The CPPRs among the Hindus have declined gradually up to the third order rather than a steep decline trend, while in the case of the Muslims a steep decline is witnessed in the fifth parity. Among the other religious groups, there has been a steep decline in CPPRs in the third order of parity. Among the Scheduled (Castes and Tribes) communities, CPPRs has recorded a steep decline in the fifth order similar to the Muslims. declining among all the religious and caste groups.

\section{Synthetic Lifetime Parity Distributions and Average Parities:}

The implied completed parity distributions, average lifetime parity, four and more parity and changes of religious and caste composition in temporal scale due to the parity change are displayed in Table 6 . The shift in the completed parity distribution is astounding and matches the substantial decline in the children ever born from $63.55 \%$ to $27.92 \%$ having four and more children during a period of four decades (19812011). Four and more parity decline trend (from 1981-2011) among the religious and caste groups recorded near equal for the Hindus (37.14 \%) and Muslims (37.27 \%) while it is comparatively slow in the scheduled population $(33.33 \%)$ and Other religious (34.21 \%) groups.

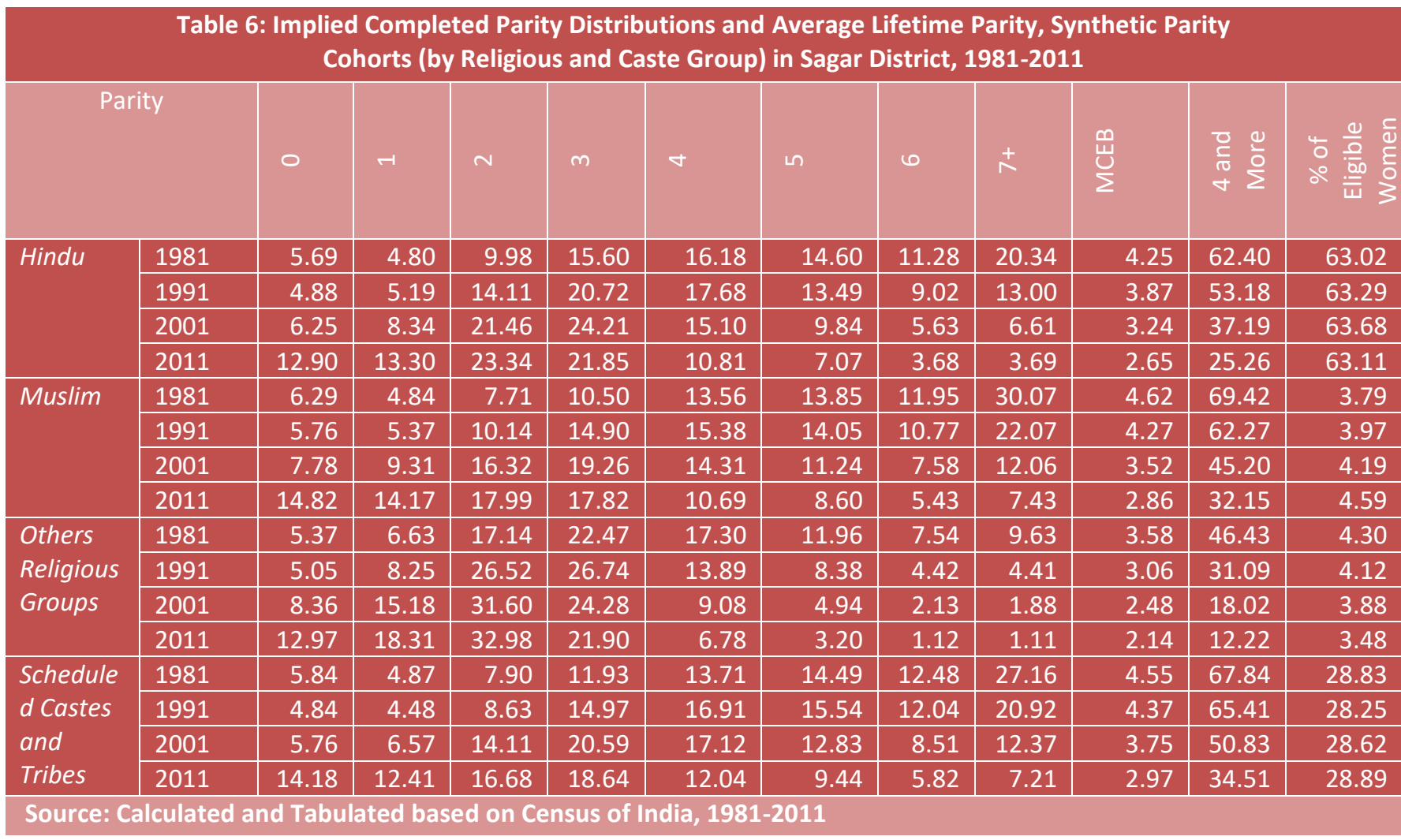

It is interesting to mention here that the declining trend is near to equal for the Hindus and Muslims, but the difference still exists, which was recorded in the year 1981. Women of the Scheduled population have $34.51 \%$ four and more parity, which is three-fold higher when 
compared to other religious and caste groups in the year 2011. Muslim women who have zero and one parity are higher than the Hindus due to the higher proportion of age above 18 years.

\section{Religious and Caste Fertility Deferential: A Test of Characteristics Hypothesis}

The difference between the adjusted and unadjusted number of MCEB (Mean Children Ever Born) among the various religious and caste groups are illustrated in Table 7 . The higher value of unadjusted mean difference among the religious and caste groups indicates the high variation in combine level due to variations in other socio-economic characteristics. Least variation in adjusted mean compared to unadjusted mean among the religious groups and castes indicates that the variation is the outcome product of other socio-economic factors which support the characteristics hypothesis. In this study, adjusted mean variation among the religious and caste groups is much lower than the unadjusted mean. This discussion reinforces the strong presence of character hypothesis in the study area.

MCA (Multiple Classification Analysis) results reveal that the unadjusted MCEB is relatively higher in Muslims, Scheduled and Hindu women than women belonging to other religious groups. Table 8 clearly indicates that more than $70 \%$ variation is responsible for socio-economic factors (education level, wealth status, place of residence and son preference) in the study area. High MCEB, which was visible among Muslims and Scheduled community (both adjusted and unadjusted mean), perhaps, is the result of a lower percentage of higher education, lower economic status and lower use of contraceptives. The lower use of contraceptives among Muslim women may be due to their religious belief (lyer, 2002; Jalil et al., 2016; Rasheed, 2015). Besides, women belonging to the Scheduled population also have less adoption due to lack of awareness.

Table 7: Assessment of Religion and Selected Socioeconomic Variables Interaction Effect on Mean Children Ever Born

\begin{tabular}{|c|c|c|c|c|c|}
\hline \multirow[t]{2}{*}{ Socio-economic Variables } & \multirow{2}{*}{$\begin{array}{c}\text { Cases } \\
(\mathrm{N})\end{array}$} & \multicolumn{2}{|c|}{ Predicted Mean } & \multicolumn{2}{|c|}{ Deviation } \\
\hline & & Unadjusted & Adjusted for Factors & Unadjusted & Adjusted for Factors \\
\hline \multicolumn{6}{|l|}{ Religion } \\
\hline Hindu excludes Scheduled & 425 & 3.06 & 3.25 & -.300 & -.113 \\
\hline Muslim & 67 & 3.96 & 3.80 & .594 & .444 \\
\hline Others & 33 & 2.15 & 3.15 & -1.210 & -.211 \\
\hline Scheduled & 375 & 3.70 & 3.43 & .340 & .068 \\
\hline \multicolumn{6}{|l|}{ Women Education Level } \\
\hline No education & 344 & 4.44 & 4.34 & 1.078 & .982 \\
\hline Primary standard & 284 & 3.12 & 3.11 & -.238 & -.251 \\
\hline High school & 193 & 2.29 & 2.41 & -1.071 & -.946 \\
\hline Intermediate & 30 & 2.43 & 2.43 & -.928 & -.929 \\
\hline Graduation and above & 49 & 1.96 & 2.22 & -1.402 & -1.140 \\
\hline \multicolumn{6}{|l|}{ Place of Residence } \\
\hline Urban & 202 & 2.94 & 3.62 & -.421 & .261 \\
\hline Rural & 698 & 3.48 & 3.29 & .122 & -.076 \\
\hline \multicolumn{6}{|l|}{ Wealth Status } \\
\hline Lowest & 332 & 3.86 & 3.40 & .494 & .038 \\
\hline Second & 200 & 3.64 & 3.44 & .284 & .080 \\
\hline Middle & 133 & 3.17 & 3.35 & -.196 & -.011 \\
\hline Fourth & 125 & 2.60 & 3.21 & -.761 & -.146 \\
\hline Highest & 110 & 2.45 & 3.28 & -.907 & -.082 \\
\hline \multicolumn{6}{|l|}{ Son Preference } \\
\hline No & 450 & 2.77 & 2.93 & -.588 & -.427 \\
\hline Yes & 450 & 3.95 & 3.79 & .588 & .427 \\
\hline
\end{tabular}


The present study confirms that the socioeconomic condition of Muslim and Scheduled population has a pivotal role in their fertility behaviour and its decision-making. Consequently, it has recorded a high fertility level in the study area.

As stated above, ANOVA analyses were deployed to examine the interaction relationships between religion and socio-economic characteristics on fertility differentials; the results of which are displayed in Table 8 . The MCA result depicts that religion, education level of women and son preference have high statistical significance ( $1 \%)$, while the place of residence has a low level (5\%). On the other hand, wealth status has recorded no significance at all.

\begin{tabular}{|c|c|c|c|c|c|}
\hline \multirow[t]{2}{*}{ Source of Variance } & \multicolumn{5}{|c|}{ Hierarchical Method } \\
\hline & $\begin{array}{l}\text { Sum of } \\
\text { Squares }\end{array}$ & $\begin{array}{c}\text { Degree } \\
\text { of } \\
\text { Freedom }\end{array}$ & $\begin{array}{l}\text { Mean } \\
\text { Square }\end{array}$ & $\mathrm{F}$ & $\begin{array}{c}\text { Significance } \\
\text { of } F\end{array}$ \\
\hline \multicolumn{6}{|l|}{ Main Effects } \\
\hline (combined) & 911.483 & 13 & 70.114 & 16.060 & .000 \\
\hline Religion & 157.940 & 3 & 52.647 & 12.059 & .000 \\
\hline Women of education level & 607.051 & 4 & 151.763 & 34.763 & .000 \\
\hline Place of residence & 6.186 & 1 & 6.186 & 1.417 & .234 \\
\hline wealth index & 8.582 & 4 & 2.146 & .491 & .742 \\
\hline Son preference & 131.724 & 1 & 131.724 & 30.173 & .000 \\
\hline \multicolumn{6}{|l|}{ Two-way interactions } \\
\hline (combined) & 911.483 & 13 & 70.114 & 16.060 & .000 \\
\hline Religion $\mathrm{x}$ education & 764.991 & 7 & 109.284 & 24.269 & .000 \\
\hline Religion $\mathrm{x}$ Place of residence & 201.155 & 4 & 50.289 & 9.805 & .000 \\
\hline Religion $\mathrm{x}$ wealth index & 336.012 & 7 & 48.002 & 9.614 & .000 \\
\hline Religion $\times$ Son preference & 416.628 & 4 & 104.157 & 21.326 & .000 \\
\hline Place of residence $\mathrm{x}$ wealth index & 285.186 & 5 & 57.037 & 11.319 & .610 \\
\hline Place of residence $\mathrm{x}$ Son preference & 310.379 & 2 & 155.189 & 31.079 & .000 \\
\hline wealth index $x$ Son preference & 482.402 & 5 & 96.480 & 20.039 & .000 \\
\hline \multicolumn{6}{|l|}{ Three-way interactions } \\
\hline (combined) & 540.440 & 9 & 60.049 & 12.588 & .000 \\
\hline Religion $\mathrm{x}$ Place of residence $\mathrm{x}$ wealth index & 336.652 & 8 & 42.082 & 8.420 & .000 \\
\hline Religion $\mathrm{x}$ Place of residence $\mathrm{x}$ Son preference & 446.046 & 5 & 89.209 & 18.371 & .000 \\
\hline Religion $\mathrm{x}$ wealth index $\mathrm{x}$ Son preference & 539.926 & 8 & 67.491 & 14.163 & .000 \\
\hline Place of residence $\mathrm{x}$ wealth index $\mathrm{x}$ Son preference & 486.122 & 6 & 81.020 & 16.824 & .000 \\
\hline \multicolumn{6}{|l|}{ Four-way interactions } \\
\hline $\begin{array}{l}\text { Religion } \mathrm{x} \text { Place of residence } \mathrm{x} \text { wealth index } \mathrm{x} \text { Son } \\
\text { preference }\end{array}$ & 506.912 & 4 & 126.728 & 26.505 & .000 \\
\hline Model & 911.483 & 13 & 70.114 & 16.060 & .000 \\
\hline Residual & 3798.132 & 870 & 4.366 & & \\
\hline Total & 4709.614 & 883 & 5.334 & & \\
\hline The overall goodness of fit & \multicolumn{5}{|c|}{ Multiple $R=.440, R^{2}=.194$} \\
\hline
\end{tabular}

\section{Religion and Women's Education Level}

Education is one of the powerful weapons to control TFR in any region or country (Das and Das, 2018; Som and Mishra, 2017; Patidar, 2018;). Girls who achieve a secondary level of education are more aware of reproductive health, and they can decide their fertility preference (Basu, 2002). The MCA results show that a difference of 1.02 (children) between the Hindus, Other groups and Muslim communities and 0.71 (children) between the Hindus, Others and Scheduled women after factoring in the 
effect of other relevant socio-economic parameters have been recorded. Table 9 unveils that there remains a strong interaction between religion, women's education and their effect on fertility, which stands at $\eta=0.403$.

\section{Religion and Place of Residence}

Table 9 shows that the religion to son preference has a moderate interaction effect on fertility $(n=0.207)$. The adjusted MCEB is higher in an urban area than in rural area while for unadjusted mean itis reverse. Moreover, rural- urban MCEB unadjusted mean controlled by other socio-economic factors differs in this place of residence.

\section{Religion and Wealth Status}

Table 9 illustrates that the interaction effect with religion and wealth has a moderate impact $(\eta=0.267)$. Women of both poor and rich wealth status have a higher difference in MCEB, and it is least in the third and fourth stage of wealth status. This result proved the inverse ' $U$ ' shape relationship of fertility with wealth status.

\begin{tabular}{|c|c|c|c|}
\hline Category & Variables & $n$ & $\beta$ \\
\hline \multirow[t]{4}{*}{ (A) } & Religion x Women Education & .403 & .162 \\
\hline & Place of Residence & .110 & .054 \\
\hline & Wealth index & .244 & .043 \\
\hline & Son preference & .239 & .171 \\
\hline \multirow[t]{4}{*}{ (B) } & Religion $x$ Place of Residence & .207 & .043 \\
\hline & Women Education & .396 & .349 \\
\hline & Wealth index & .244 & .043 \\
\hline & Son preference & .239 & .171 \\
\hline \multirow[t]{4}{*}{ (C) } & Religion $\mathrm{x}$ Wealth status & .267 & .071 \\
\hline & Women Education & .396 & .349 \\
\hline & Place of Residence & .110 & .054 \\
\hline & Son preference & .239 & .171 \\
\hline \multirow[t]{4}{*}{ (D) } & Religion $\mathrm{x}$ Son preference & .297 & .088 \\
\hline & Women Education & .396 & .349 \\
\hline & Place of Residence & .110 & .171 \\
\hline & Wealth index & .244 & .043 \\
\hline \multicolumn{2}{|l|}{ Total } & Multiple $R=.440$ & $\mathrm{R}^{2=} .194$ \\
\hline
\end{tabular}

\section{Religion and Son Preference}

The social pressure on women to produce at least one male child for old age security often leads to the birth of several female children triggering a larger family size is a common phenomenon in India (Edmeades et al., 2011). Couples and their family preference for son are considered as an essential factor which influences the fertility decisions taken by them (Das, 1987, Jalil et al., 2016; Muthurayappa et al., 1997). In Sagar district, Muslim women (56.72 \%) have a higher preference for a son when compared to the Hindus (49.38\%) and Other (51.52) religious groups. It is apparent from
Table 9, which shows that the interaction effect with religion and son preference has a significant impact on fertility ( $\eta=0.267)$. Differential Contraceptive Adoption (Findings from Logistic Regression Analysis)

Contraception is the method to avoid unwanted pregnancy through temporary or permanent ways of achieving sustainable development by the process of population stabilisation (PRB, 2017). Several researchers proved that the religious fertility differentials are mostly due to the differential use of contraceptives especially in the religious group of the Hindus and Muslims (Balasubramanian, 1984; Bhagatand Paharaj, 
2005; Mistry, 1994 and Haque\& Patel, 2016). model on contraceptive use among the married Summary results of the binary logistic regression women are shown in Table 10.

\begin{tabular}{|c|c|c|c|c|c|}
\hline \multirow[t]{2}{*}{ Explanatory Variables } & \multirow{2}{*}{$\begin{array}{l}\text { Reference } \\
\text { Category }\end{array}$} & \multicolumn{4}{|c|}{ Odds Ratio of Contraceptive Use } \\
\hline & & $\begin{array}{l}\text { Hindu } \\
\text { excluded } \\
\text { Scheduled } \\
\end{array}$ & Muslim & Others & Scheduled \\
\hline Total Case & $\mathrm{N}=900$ & 425 & 67 & 33 & 375 \\
\hline Type of residence & Rural & 1.000 & 1.000 & 1.000 & 1.000 \\
\hline Urban & & $2.081^{*}$ & $4.572^{*}$ & $3.975^{*}$ & $2.207 * *$ \\
\hline $\begin{array}{l}\text { Women's Education } \\
\text { Level }\end{array}$ & upto Secondary & 1.000 & 1.000 & 1.000 & 1.000 \\
\hline Secondary and Above & & $4.440 * * *$ & $1.425 *$ & $1.731^{*}$ & $1.553 *$ \\
\hline $\begin{array}{l}\text { Women Age Group } \\
\text { (Years) }\end{array}$ & $20-29$ & 1.000 & 1.000 & 1.000 & 1.000 \\
\hline Less than 19 Years & & $-0.138 * * *$ & 1.133 & -------- & $-0.329 * *$ \\
\hline $30-39$ & & $2.497 * * *$ & $1.653^{*}$ & $3.467^{*}$ & $1.924 * *$ \\
\hline $40-49$ & & $-0.758 *$ & $-0.567^{*}$ & -------- & 1.101 \\
\hline Son Prefernce & $\begin{array}{l}\text { Parity } \\
\text { Eiqulibrium (No } \\
\text { Preference) }\end{array}$ & 1.000 & 1.000 & 1.000 & 1.000 \\
\hline Son Preference & & $0.734^{*}$ & 1.153 & $3.685^{*}$ & $0.458 * * *$ \\
\hline Age at Marriage & Below 18 years & 1.000 & 1.000 & 1.000 & 1.000 \\
\hline 18 years and above & & $0.760 *$ & $0.105^{*}$ & 8.891 & $1.906 * * *$ \\
\hline Wealth Status & Highest & 1.000 & 1.000 & 1.000 & 1.000 \\
\hline Lowest & & $-0.671^{*}$ & $0.008 * * *$ & --- & $-0.543^{*}$ \\
\hline Second & & $-0.565^{*}$ & $0.025 * * *$ & 2.551 & $-0.494^{*}$ \\
\hline Middle & & -0.963 & $-0.143 * *$ & 2.551 & $-0.485^{*}$ \\
\hline Fourth & & $-0.682^{*}$ & 3.231 & $-0.474^{*}$ & -0.790 \\
\hline $\begin{array}{l}\text { Number of Living } \\
\text { Children }\end{array}$ & Up to Two Child & 1.000 & 1.000 & 1.000 & 1.000 \\
\hline More than Two Child & & $3.255 * * *$ & $0.060 *$ & $0.331 *$ & $8.357^{* * *}$ \\
\hline
\end{tabular}

The analysis of the likelihood of contraceptive adoption among currently married women of different religions and castes were conducted using the logistic regression analysis in Sagar district. The Odd ratio has also been used for each group separately to examine the difference of likelihood of contraception. In the case of Hindu and Scheduled Castes and Tribes women, all the variables are statistically significant. On the other hand, preference of son among the Muslim women and age at marriage in case of Scheduled Castes and Tribes women are not statistically significant.

\section{The Contribution of Change in Religious and Caste composition on Fertility Decline:}

The Decomposition analysis has been used to identify how religious and caste composition 
contributes to the change in mean children ever born at two points of time (1981 to 2011). Table 11 unravels the decomposition of the change in religious and caste composition, which affects the decline in fertility during the period 1981 to 1991, 1991 to 2001, 2001 to 2011 and 1981 to 2011. This Table shows that MCEB in Sagar district has fallen from 4.33 in 1981 to 3.99 in 1991 and 3.37 in 2001 to 2.74 in 2011, but the rate of decrease was higher in the last decade.
The role of Hindu excluding the Scheduled Castes and Tribes population and other religions in the change of fertility behaviour has dramatically declined from 1981-1991 to 20012011 (Table 11). Among the scheduled community and Muslim population, it has phenomenally increased during the period. Thus, it is therefore concluded that religion and caste composition has a direct impact on the fertility change in the study area.

\begin{tabular}{|c|c|c|c|c|c|c|}
\hline \multirow[t]{2}{*}{ Educational Level of Women } & \multicolumn{2}{|c|}{ Census 1981} & \multicolumn{2}{|c|}{ Census 1991} & \multicolumn{2}{|c|}{$\begin{array}{c}\text { Within Class Decline } \\
\text { In MCEB }\end{array}$} \\
\hline & MCEB & $\begin{array}{c}\% \\
\text { Women }\end{array}$ & MCEB & $\begin{array}{c}\% \\
\text { Women }\end{array}$ & MCEB & $\%$ Women \\
\hline Hindu (exclude Scheduled) & 4.25 & 63.20 & 3.87 & 63.29 & -0.24 & 71.97 \\
\hline Muslim & 4.62 & 3.79 & 4.27 & 3.97 & -0.01 & 4.07 \\
\hline Other Religion & 3.58 & 4.30 & 3.06 & 4.12 & -0.02 & 6.56 \\
\hline Scheduled & 4.55 & 28.89 & 4.37 & 28.62 & -0.05 & 15.50 \\
\hline \multirow[t]{2}{*}{ Educational Level of Women } & \multicolumn{2}{|c|}{ Census 1991} & \multicolumn{2}{|c|}{ Census 2001} & \multicolumn{2}{|c|}{$\begin{array}{l}\text { Within Class Decline } \\
\text { In MCEB }\end{array}$} \\
\hline & MCEB & $\begin{array}{r}\% \\
\text { Women }\end{array}$ & MCEB & $\begin{array}{r}\% \\
\text { Women }\end{array}$ & MCEB & \% Women \\
\hline Hindu (exclude Scheduled) & 3.87 & 63.29 & 3.24 & 63.68 & -0.40 & 63.56 \\
\hline Muslim & 4.27 & 3.97 & 3.52 & 4.19 & -0.03 & 4.86 \\
\hline Other Religion & 3.06 & 4.12 & 2.48 & 3.88 & -0.02 & 3.69 \\
\hline Scheduled & 4.37 & 28.62 & 3.75 & 28.25 & -0.18 & 28.02 \\
\hline \multirow[t]{2}{*}{ Educational Level of Women } & \multicolumn{2}{|c|}{ Census 2001} & \multicolumn{2}{|c|}{ Census 2011} & \multicolumn{2}{|c|}{$\begin{array}{c}\text { Within Class Decline } \\
\text { In MCEB }\end{array}$} \\
\hline & MCEB & $\begin{array}{r}\% \\
\text { Women }\end{array}$ & MCEB & $\begin{array}{r}\% \\
\text { Women }\end{array}$ & MCEB & $\%$ Women \\
\hline Hindu (exclude Scheduled) & 3.24 & 63.68 & 2.65 & 63.11 & -0.37 & 59.19 \\
\hline Muslim & 3.52 & 4.19 & 2.86 & 4.59 & -0.03 & 4.59 \\
\hline Other Religion & 2.48 & 3.88 & 2.14 & 3.48 & -0.01 & 1.98 \\
\hline \multirow[t]{2}{*}{ Scheduled } & 3.75 & 28.25 & 2.97 & 28.83 & -0.22 & 35.23 \\
\hline & \multicolumn{2}{|c|}{ Census 1981} & \multicolumn{2}{|c|}{ Census 2011} & \multicolumn{2}{|c|}{$\begin{array}{c}\text { Within Class Decline } \\
\text { In MCEB }\end{array}$} \\
\hline Hindu (exclude Scheduled) & 4.25 & 63.20 & 2.65 & 63.11 & -1.01 & 63.35 \\
\hline Muslim & 4.62 & 3.79 & 2.86 & 4.59 & -0.07 & 4.62 \\
\hline Other Religion & 3.58 & 4.30 & 2.14 & 3.48 & -0.06 & 3.51 \\
\hline Scheduled & 4.55 & 28.89 & 2.97 & 28.83 & -0.46 & 28.59 \\
\hline
\end{tabular}

\section{Conclusion}

The present research aimed to examine the impact of religions and castes on fertility behaviour among women in the district of Sagar in Madhya Pradesh. For this, the research deployed quantitative techniques-Multiple 
Classification Analysis, Logistic Regression Analysis and Decomposition Analysis. The findings reveal that religion and castes do play key roles in fertility behaviour and preference for a son. Besides, socio-economic characteristics such as educational level, age at marriage and wealth status also bear an impact on fertility behaviour.

While this research was conducted only in Sagar district, it is difficult to make generalisation. However, this research provides a firm ground for similar research to be conducted in other parts of the state.

\section{References}

Alagarajan, Manoj and Kulkarni, P.M. (1998). Fertility differentials by religion in Kerala: a period parity progression ratio analysis. Demography India, 27(1), 213-227.

Arora, G (1985). Caste socio-economic status and fertility-a study of proximate determinants of fertility in village Riwasa. Guru Nanak Journal of Sociology, 6(2), 81-96.

Arokiasamy, P., (2002). Gender preference, contraceptive use and fertility in India: Regional and development influences. International Journal of Population Geography, 8(1), 49-67.

Balasubramanian, K., (1984). Hindu-Muslim differentials in fertility and population growth in India: role of proximate variable. Artha Vijnana, 26(3), 189-216.

Barooah, M., (2014). Spatial Pattern and Variation in Literacy among the Scheduled Castes Population in the Brahmaputra Valley, Assam. Space and Culture, India, 2(1), 24-32. https://doi.org/10.20896/saci.v2i1.68

Basu, A. M. (2002). Why does education lead to lower fertility? A critical review of some of the possibilities. World Development.30 (10):17791790.

Bhagat, R. B. \&Praharaj, P. (2005). Hindu-Muslim fertility differentials. Economic and Political Weekly, 411-418.

Bhat, P. N. M. (2002). Returning a favor: Reciprocity between female education and fertility in India.World Development, 30(10), 1791-1803.

Bhattacharyya, Rituparna, (2009). Examining the changing status and role of middle class Assamese women: Lessons from the lives of university students, PhD thesis. Newcastle University, UK.

Bhattacharyya, R., (2013). Are We Empowered? Stories of young Indian working women, Saarbrücken, Germany: Lap Lambert Academic Publishing, (ISBN: 978-3-659-20580-4)

Bhattacharyya, Rituparna and Singh, Suman(2018). Exclusion (and seclusion): Geographies of Disowned Widows of India, GeoJournal, 83 (4), 757-774, DOI: $10.1007 / \mathrm{s} 10708-017-9800-0$

Census of India (2011). Fertility Tables (F-Series). Registrar General India: New Delhi.

Das, K., \& Das, M., (2018). Women And Wedlock: A Study On Female Marital Status Among the Hindus, Muslims and Christians of Assam, India. Space and Culture, India, 6(1), 107-119. https://doi.org/10.20896/saci.v6i1.294

Das, N and D Pandey (1985). Fertility differentials by religion in India: An analysis of 1971 census fertility data. Canadian Studies in Population, 12(2), 119-136.

Das, N., (1987). Sex preference and fertility behavior: A study of recent Indian data. Demography, 24(4), 517-530.

Day, L. H. (1984). Minority-group status and fertility: a more detailed test of hypothesis. The Sociological Quarterly, 25(4), 456-472.

Edmeades, J., Pande, R. P., Falle, T., \& Krishnan, S. (2011). Son preference and sterilisation use among young married women in two slums in Bengaluru city, India. Global public health, 6(4), 407-420.

Frejka, T. \&Sardon, J. P. (2007). Cohort birth order, parity progression ratio and parity distribution trends in developed countries. Demographic Research, 16(11), 315-374.

Goldscheider, C and Uhlenberg, P. R. (1969). Minority group status and fertility. American Journal of Sociology, 74(4), 361-373. 
Haque, I., \& Patel, P. P. (2016).Assessing HinduMuslim Fertility Differentials in West Bengal: Insights from the National Family Health Survey3 Data. Journal of Family History, 41(2), 192-224.

Holzer-Zelazewska, D., \&Tymicki, K., (2009).Cohort and period fertility of Polish women 1945-2008. Studia Demograficzne, 155(1), 48-69.

Iyer, S., (2002). Demography and religion in India. Oxford University Press, USA.

Jalil, A., Zakar, R., Usman, A., \&Amjad, A. (2016).Determinants of fertility and fertility preferences in Pakistan: Comparative Secondary Analysis of PDHS 2007-2013. Pakistan Journal of Gender Studies, 12, 19-38.

Kulkarni, P. M. (March 2002). Special Population Groups. In SEMINAR, New-Delhi, 58-86, MALIYIKA SINGH.

Mistry, M. B., (1994).Hindu-Muslim fertility differentials in India. Journal Institute of Muslim Minority Affairs, 15(1-2), 171-182.

Mutharayappa, R., (1997). Son preference and its effect on fertility in India.

Patidar, H., (2018). Women's Empowerment and Fertility Behaviour among the Tribals of Rajasthan, India. Space And Culture, India, 5(3), 129-139. doi:10.20896/saci.v5i3.285

Population Reference Bureau, (2017). To New Policy, briefs focus on sustainable development goals in Pakistan and Malawi. http://www.prb.org/Publications/Reports/2017 /From-the-Health-Policy-Plus-Project.aspx

Ramesh, P., (2007). Analysis of fertility differentials among caste groups in Andhra Pradesh (An).

Rasheed, N. Khan, Z. Khalique, N. Siddiqui, A. R.\&, Hakim, S. (2015). Family planning differentials among religious groups: A study in India. International Journal of Medicine and Public Health, 5(1).
Reddy, P. H., (2003). Religion, population growth, fertility and family planning practice in India. Economic and Political Weekly, 3500-3509.

Risley, H. H., (1891). The tribes and castes of Bengal, Government of India, 1, Calcutta.

Roy, S., Singh, K.K., Singh, B. P., Gupta, K. (2015).Study of the influence of caste differentials on fertility and contraception. Journal of Statistics Application and Prob. Letters, 2, 149-160.

Shariff, A., (1995). Socio-economic and demographic differentials between Hindu and Muslim in India. Economic and Political Weekly, 2947-2952.

Som, K. S. and Mishra, R. P. (2017a). Education, religion, development and regional patterns of fertility in West Bengal. Indian Journal of Spatial Science. 8(1): 1-8, Spring Issues.

Som, K., \& Mishra, R. P. (2017b). An Inter-District Efficiency Measurement of RCH Program Using Data Envelopment Analysis in Madhya Pradesh, India. Space and Culture, India, 5(2), 84-96. https://doi.org/10.20896/saci.v5i2.267

Som, K. S., \& Mishra, R. P. (2014). BIMARU States: Need a Rethinking. IOSR Journal of Humanities and Social Science, 19(7), 34-41. doi: 10.9790/0837-19713441

United Nations, Department of Economic and Social Affairs, Population Division (2009). World Marriage Data 2008 (POP/DB/Marr/ Rev2008).

Visaria, Leela, (1974). Religious Differentials in Fertility. In Ashis Bose et al. (eds.), Population in India's Development,1947-2000, Vikas Publishing House, Delhi.

Yadava, R. C., Kumar, A., \& Pratap, M. (2009). Estimation of parity progression ratios from open and closed birth interval data. Journal of Data Science, 11(3), 607-621. 